PNL-2413

UC-70

\title{
Analysis of the Impact of Retrievable Spent Fuel Storage
}

March 1978

Prepared for the U.S. Department of Energy under Contract EY-76-C-06-1830

Pacific Northwest Laboratory Operated for the U.S. Department of Energy by 


\title{
NOTHCE
}

This report was prepared as an account of work sponsored by the United States Government, Neither the United States not the Department of Energy not any of their employees, nor any of their contractors, subcontractors, or their empiovees, makesany watranty, express or implied, or assumes any legal liability or responsibility for the accuracy, completeness or usefuiness of any information, apparatus, product or procass disclosed, or represents that its use would not intringe privatily owned rights.

The views, opinions and conclusions contained in this report are those of the contractor and do roi necessarily represent those of the United States Goverrment or the United Shates Deparment of Enerzy.

\author{
PACIFIC NORTHWEST LABORATORY \\ aperated by \\ BATTELLE \\ for the \\ UNITED STATES DEPARTMENT OF ENERCY \\ Under Cintract EY-75-C-06-1830
}
Printes is ithat Litred Shates at America avaliable tram

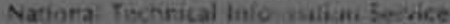
Unired Siares Department at Commence
5.,85 Port Roval Hexd
Spring' ele. Mirgents 247

Fice: Ptinted Copy 3 .

Anticraticte sios

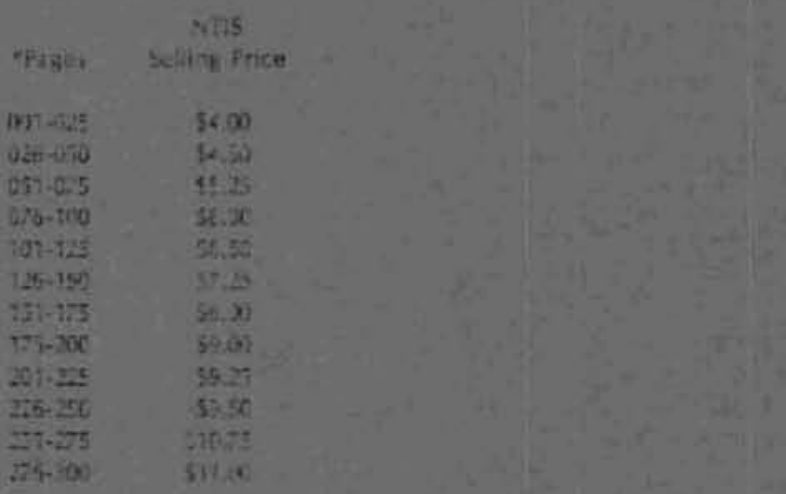


PNL -2413

UC -70

\section{1}

ANALYSIS OF THE IMPACT OF RETRIEVABLE SPENT FUEL STORAGE

E. T. Merril1

M. K. White

R. M. Fleischman

March 1978

Prepared for

the U.S. Department of Energy under Contract EY-76-C-06-1830

Pacific Northwest Laboratoy

Richland Washington 99352 



\section{CONTENTS}

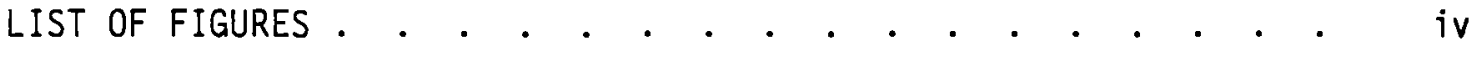
LIST OF TABLES . . . . . . . . . . . . . . . . . . . . . . .

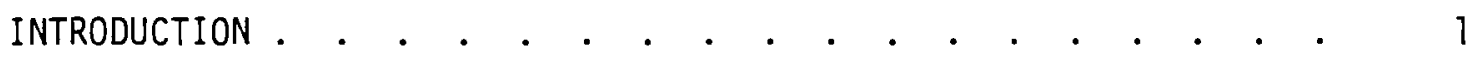
SUMMARY AND CONCLUSION. . . . . . . . . . . . . . . . . 1 DISCUSSION. . . . . . . . . . . . . . . . . . . . 2 LWR RECYCLE . . . . . . . . . . . . . . . . . . 4 LMFBR INTRODUCTION . . . . . . . . . . . . . . . . . . 5

Period of Retrievable Storage. . . . . . . . . . . 7 MODIFIED LWR GROWTH SCHEDULE. . . . . . . . . . . . . 9 ANALYSIS ASSUMPTIONS . . . . . . . . . . . . . . . 12 


\section{LIST OF FIGURES}

1. Potential Additional Energy from LWR Recycle . . . . . . 5

2. Installed LMFBR Generating Capacity Resulting from a 1985 Decision Date . . . . . . . . . . . . . . . . 6

3. Installed LMFBR Generating Capacity Resulting from a 1990 Decision Date. . . . . . . . . . . . . . 6

4. Installed LMFBR Capacity Resulting from a 2000 Decision Date. 7

5. Potential LMFBR Generating Capacity in 2040 . . . . . . 8

6. Potential Additional Energy from LWR Recycle. . . . . . 10

7. Potential LMFBR Generating Capacity in 2040 . . . . . 11 
$\underline{\text { LIST OF TABLES }}$

1. LWR Growth Schedule Utilizing $3.7 \times 10^{6}$ Tons $U_{3} \mathrm{O}_{8} \cdot$. $\cdot$. 3

2. MT Fuel Terminally Stored . . . . . . . . . . . . 4

3. Maximum Spent Fuel Storage Time (years). . . . . . . . 8

4. Maximum Spent Fuel Storage Time (years). . . . . . . . 9

5. LWR Growth Schedule for Utilizing $2.2 \times 10^{6}$ Tons $\mathrm{U}_{3} \mathrm{O}_{8} \cdot$. . 10

6. Pu Flows for HEDL Large Pin, 800 MW, 2500 MW LMFBR . . . 12

v 



\section{ASSESSMENT OF THE BENEFIT OF \\ RETRIEVABLE SPENT FUEL STORAGE}

\section{INTRODUCTION}

The purpose of retrievable storage of spent fuel is to avoid foreclosing the long-term options for spent fuel management. The ultimate disposition of spent fuel will depend on the strategy adopted for long-term nuclear power development. The selection of a preferred strategy for future nuclear development is currently the subject of intense study, focusing on fuel cycles with improved nonproliferation attributes.

This analysis evaluates the impact of varying degrees of spent fuel retrievability. The chosen bases for evaluating impact are recycling uranium and plutonium in light water reactors (LWRs) and implementing a decision to build liquid metal fast breeder reactors (LMFBRs). This does not imply a recommendation of these particular nuclear development pathways. These options were selected as the basis for analysis for the following reasons:

1) LWR recycle and LMFBR introduction are the best understood of the alternative nuclear development pathways under consideration; therefore they are more easily analyzed.

2) Spent fuel is the plutonium source for the advanced reactor systems under consideration that require plutonium. The LMFBR has historically been viewed as an efficient use for plutonium. Therefore, analyzing the impact of spent fuel (and thus plutonium) disposal on the achievable LMFBR introduction rate gives insight into the generic problem of plutonium supply limitations when implementing any advanced reactor system utilizing plutonium.

\section{SUMMARY AND CONCLUSION}

The impact of retrievably storing spent fuel is measurable in terms of the contribution the stored spent fuel makes to implementing the fuel management option selected. For the case of a decision to recycle LWR fuel in LWRS, a 
useful indicator of impact is the ratio of energy production with varying degrees of spent fuel retrievability to that achievable with total spent fuel retrievability. For a decision made in the year 2000, this ratio varies from 0.81 (10 yr storage in reactor basins) to 0.97 (retrievable storage for 25 years after fuel discharge). An earlier decision to recycle in LWRs results in both of these ratios being nearer to 1.0 .

If a decision is reached to implement a breeder reactor economy, the chosen comparison is the installed breeder capacity achievable with varying degrees of spent fuel retrievability. If a decision to build breeder reactors is reached in the year 2000, the maximum possible installed breeder capacity in 2040 varies from 490 GWe (10 yr storage in reactor basins) to 660 GWe (a11 fuel retrievably stored). If all fuel is retrievably stored 25 years, 635 GWe of breeder capacity is achievable by 2040. For an earlier decision date, such as 1985, the maximum possible installed breeder capacity in 2040 ranges from 740 GWe (no retrievable storage) to 800 GWe (a11 fuel retrievably stored).

As long as a decision to reprocess is reached before 2000 , most of the potential benefit of retrievable storage may be realized by implementing retrievable storage after such a decision is made. Less than $10 \%$ of the potential benefit of LWR recycle and less than $15 \%$ of the potential breeder capacity are sacrificed if post reactor basin retrievable spent fuel storage is deferred until after a decision to reprocess has been made.

Neither providing retrievable spent fuel storage prior to a decision to reprocess, nor designing such storage for more than 25 years of retrievability appear to offer significant incremental benefit. Since the identifiable benefits of early, extended retrievable spent fuel storage appear to be small, the resources expended in achieving it should also be commensurately smal1. Detailed cost-benefit analysis would be required to quantify this tradeoff.

\section{DISCUSSION}

The analysis is based on an LWR growth schedule that reaches 380 GWe by 2000 , and continues to grow at a moderate rate until $3.7 \times 10^{6} \mathrm{ST} \mathrm{U}_{3} \mathrm{O}_{8}$ (DOE 
estimate of domestic $\mathrm{U}_{3} \mathrm{O}_{8}$ reserves) are committed. The schedule then declines by reactor retirements to zero in 2071 . This schedule is shown in Table 1 .

TABLE 1. LWR Growth Schedule Utilizing

$$
3.7 \times 10^{6} \text { Tons } \mathrm{U}_{3} \mathrm{O}_{8}
$$

\begin{tabular}{|c|c|c|c|}
\hline Year & $\begin{array}{c}\text { GWe } \\
\text { Capacity }\end{array}$ & Year & $\begin{array}{c}\text { GWe } \\
\text { Capacity }\end{array}$ \\
\hline 1980 & 66 & 2030 & 543 \\
\hline 1985 & 127 & 2035 & 468 \\
\hline 1990 & 194 & 2040 & 370 \\
\hline 1995 & 283 & 2045 & 370 \\
\hline 2000 & 380 & 2050 & 251 \\
\hline 2005 & 439 & 2055 & 191 \\
\hline 2010 & 494 & 2060 & 131 \\
\hline 2015 & 522 & 2065 & 72 \\
\hline 2020 & 553 & 2070 & 12 \\
\hline 2025 & 552 & 2071 & 0 \\
\hline
\end{tabular}

Four degrees of spent fuel retrievability were considered. These are described below.

\section{Case A: 10 Year Retrievable Storage in Reactor Bas in}

Each reactor has the capacity to store its spent fuel 10 years. At the end of 10 years fuel must be reprocessed (if capacity is available) or terminally stored. No post reactor basin retrievable spent fuel storage exists. This implies spent fuel continues to be sent to terminal storage for 10 to 15 years after the decision to reprocess, while that decision is being implemented.

Case B: 10 Year Retrievable Storage Expanded After Reprocessing Decision

This case is the same as Case $A$, except that it is assumed that if a decision is reached to reprocess spent fuel, sufficient away 
reactor (AFR) storage can be constructed in the following five years to eliminate terminal storage of any additional fuel. Thus spent fuel is sent to terminal storage for only 5 years after the decision to reprocess it is made.

\section{Case C: 25 Year Retrievable Storage}

Sufficient AFR storage is available so that spent fuel may be retrievably stored an additional 15 years after discharge. After a total of 25 years in storage it is terminally stored.

\section{Case D: Maximum Retrievable Storage}

A11 spent fuel is retrievably stored until it may be employed in implementing the selected option. No spent fuel is terminally stored.

Table 2 gives the amounts of fuel which are terminally stored for each of the four retrievability levels and three potential reprocessing decision dates.

TABLE 2. MT Fuel Terminally Stored

\begin{tabular}{lrrr} 
& \multicolumn{3}{c}{ Date of Decision } \\
\cline { 2 - 4 } & 1985 & \multicolumn{1}{c}{1990} & \multicolumn{2}{c}{2000} \\
Case A & 20,500 & 42,700 & 118,000 \\
Case B & 6,700 & 15,600 & 56,300 \\
Case C & 0 & 1,400 & 17,800 \\
Case D & 0 & 0 & 0
\end{tabular}

\section{LWR RECYCLE}

Figure 1 illustrates the benefits of increasing increments of spent fuel retrievability following a decision to reprocess spent fuel and recycle uranium and plutonium in LWRs. It shows that over $80 \%$ of the energy producing potential (Case D) of recycling spent fuel in LWRs can be realized if a decision to reprocess and recycle is reached by 2000 , even if no post reactor basin retrievable storage is provided (Case A). Over $90 \%$ of the 
energy producing potential is achieved if retrievable storage is provided after a decision to recycle is reached (Case B). Less than $3 \%$ of the energy producing potential of spent fuel is lost if fuel is retrievably stored for 25 years after discharge (Case $\mathrm{C}$ ).

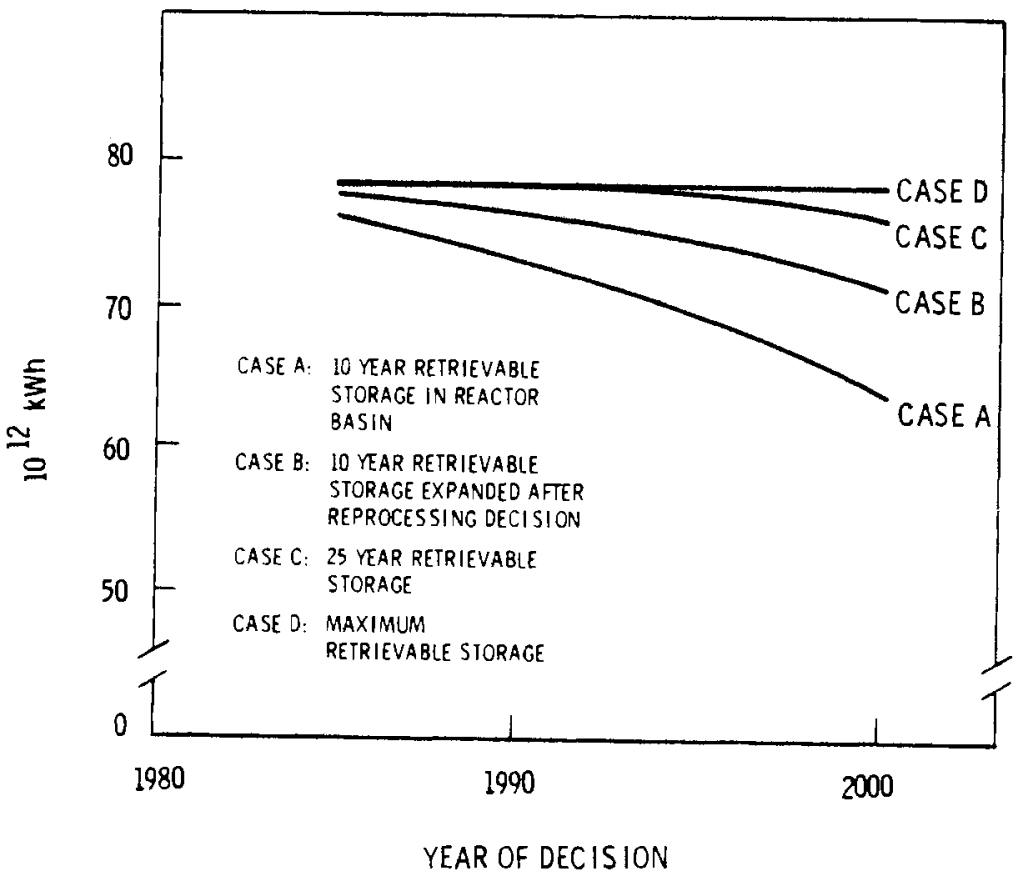

\section{FIGURE 1. Potential Additional Energy from LWR Recycle}

\section{LMFBR INTRODUCTION}

Figures 2, 3, and 4 show the maximum LMFBR growth for 1985, 1990, and 2000 decision dates. The same four degrees of retrievability as described for LWR recycle are displayed. Figure 5 summarizes these results, showing achievable LMFBR generating capacity in 2040, as a function of the reprocessing decision date, for the four levels of retrievability. The 2040 date was selected because it is long enough after each of the assumed decision dates so that breeder growth will depend on the breeder cycle doubling time rather than plutonium recovery from spent fuel. 


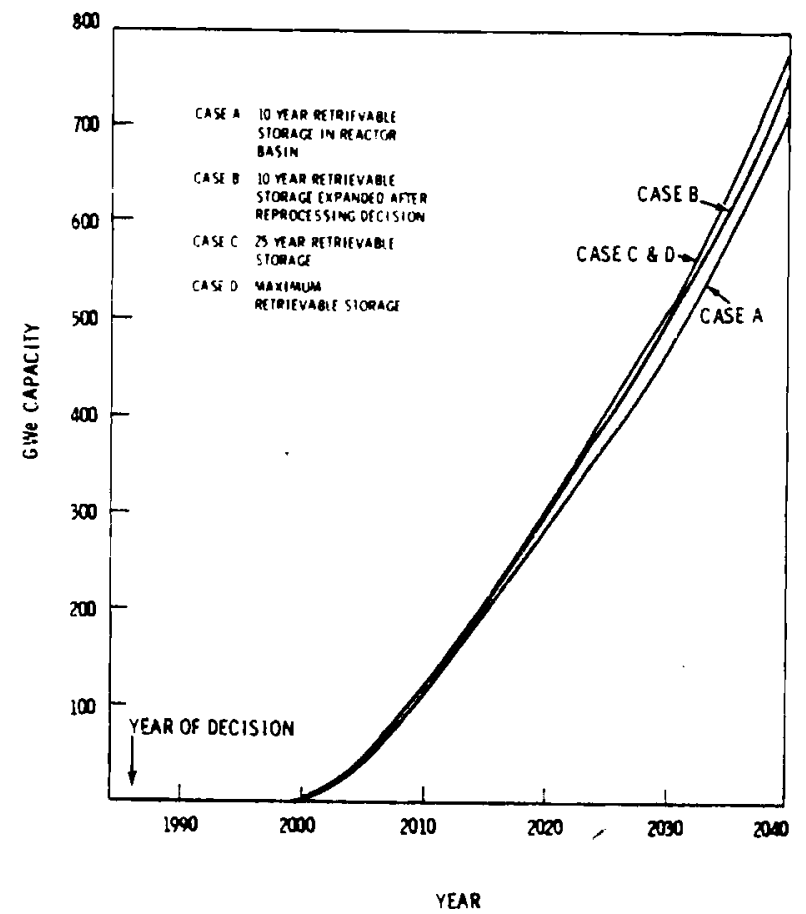

FIGURE 2. Installed LMFBR Generating Capacity Resulting from a 1985 Decision Date

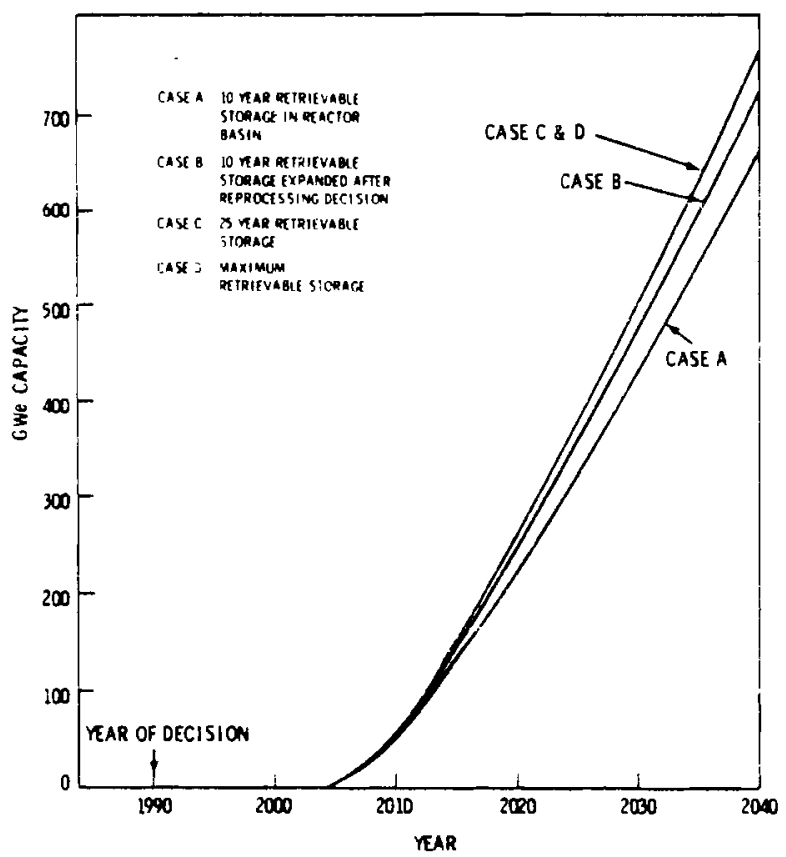

FIGURE 3. Installed LMFBR Generating Capacity Resulting from a 1990 Decision Date 


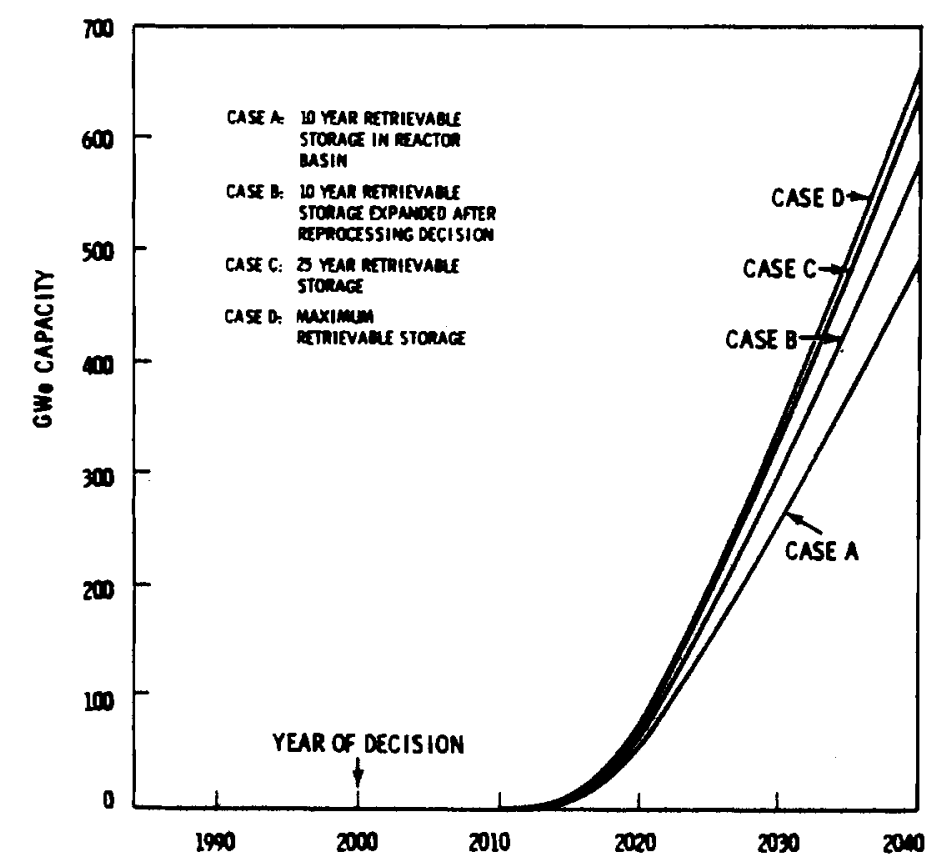

FIGURE 4. Installed LMFBR Capacity Resulting from a 2000 Decision Date

Figure 5 shows that over $74 \%$ of the potentially achievable 2040 LMFBR generating capacity (Case D) can be realized, even if no post reactor basin retrievable storage is provided (Case A). Over $87 \%$ of the potential generating capacity acievable may be reached if retrievable storage is built after a decision to build breeders is reached (Case B). Less than $4 \%$ of the potential generating capacity is lost if spent fuel is terminally stored 25 years after discharge.

\section{Period of Retrievable Storage}

The length of spent fuel storage is determined by the philosophy adopted in unloading the storage facility and the attractiveness of retrievably stored spent fuel for reprocessing relative to spent fuel in reactor basins. Table 3 gives the maximum storage times for the case where retrievably stored spent fuel is reprocessed preferentially to spent fuel in reactor basins. That is, only that fuel which must be shipped from reactor basins because of basin capacity limitations is reprocessed. The remainder of the reprocessing 
capacity is devoted to emptying the spent fuel storage facility. This might occur if the carrying charges for spent fuel in the retrievable facility were high. The two spent fuel unloading philosophies employed are first in, first out (FIFO) and last in, first out (LIFO).

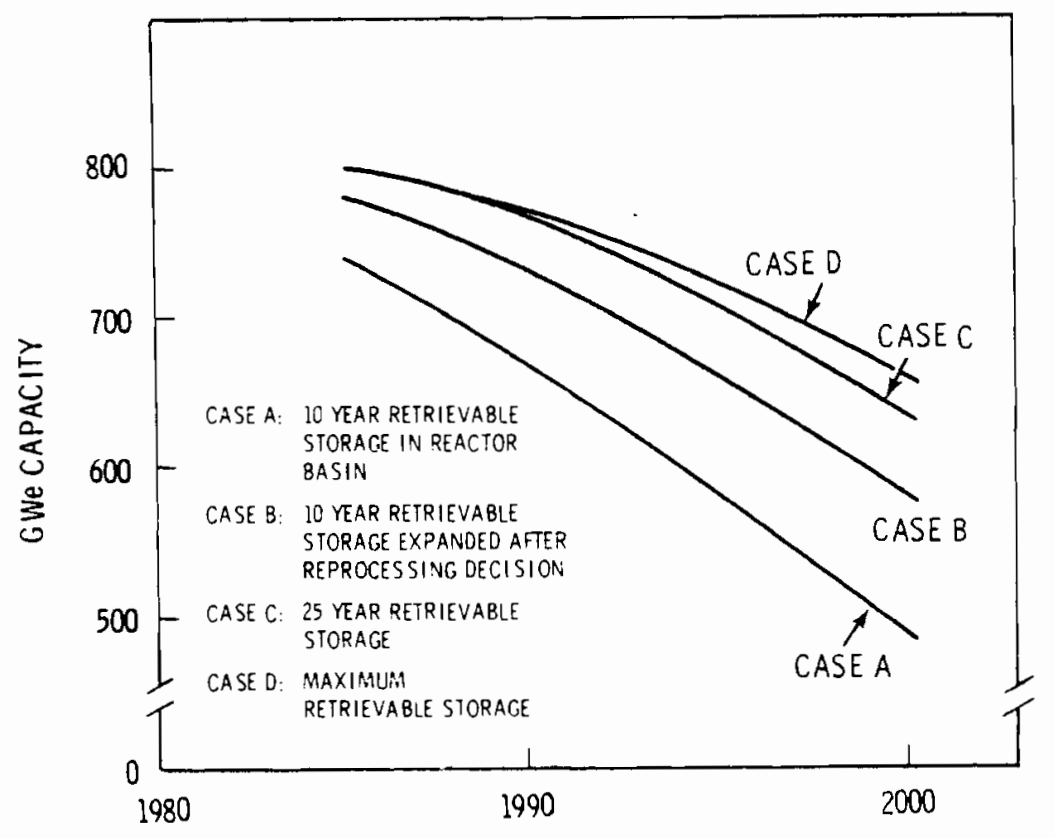

YEAR OF DECISION

FIGURE 5. Potential LMFBR Generating Capacity in 2040

TABLE 3. Maximum Spent Fuel Storage Time (years)

Date of Decision

to Build Breeder

$\underline{\text { LIFO }}$ FIFO

1985

19

15

1990

28

21

2000

44

31 
Table 4 gives the maximum spent fuel storage times if spent fuel from reactor basins is preferentially reprocessed. This case would result if the retrievable storage scheme made it significantly more difficult to reprocess spent fuel.

TABLE 4. Maximum Spent Fuel Storage Time (years)

\begin{tabular}{cccc}
$\begin{array}{c}\text { Date of Decision } \\
\text { to Build Breeder }\end{array}$ & LIFO & FIF0 \\
\cline { 1 - 1 } 1985 & 33 & 27 \\
1990 & 38 & 33 \\
2000 & 50 & 40
\end{tabular}

The LIFO storage times in Table 4 are the maximum stored times for which retrieved spent fuel is useful in support of breeder growth. This is seen by inspecting Figures 2, 3, and 4, and noting that the horizontal displacement is less than one year between curves $C$ and $D$. This indicates that if the breeder growth curve slips by as little as one year, no fuel in storage more than 25 years need be recovered to support breeder growth. Also, for a one year slippage in the breeder growth schedule following a 1985 decision to reprocess, no fuel retrieval is required (Curves $A$ and $D$, Figure 2).

\section{MODIFIED LWR GROWTH SCHEDULE}

Identical analyses were performed based on a modified LWR growth scenario which reaches 400 GWe installed by 2000 and declines by reactor retirements to zero in 2040. This scenario is illustrative of the situation where less $\mathrm{U}_{3} \mathrm{O}_{8}\left(2.2 \times 10^{6} \mathrm{ST} \mathrm{U}_{3} \mathrm{O}_{8}\right)$ is utilized. This schedule is given in Table 5 . 
TABLE 5. LWR Growth Schedule for Utilizing $2.2 \times 10^{6}$ Tons $\mathrm{U}_{3} \mathrm{O}_{8}$

\begin{tabular}{|c|c|c|c|}
\hline Year & GWe Capacity & Year & GWe Capacity \\
\hline 1980 & 60 & 2015 & 364 \\
\hline 1985 & 127 & 2020 & 340 \\
\hline 1990 & 194 & 2025 & 274 \\
\hline 1995 & 293 & 2030 & 206 \\
\hline 2000 & 400 & 2035 & 108 \\
\hline 2005 & 399 & 2040 & 0 \\
\hline 2010 & 395 & & \\
\hline
\end{tabular}

Figure 6 illustrates the benefits of increasing increments of spent fuel retrievability following a decision to reprocess spent fuel and recycle uranium and plutonium in LWRs. It should be noted that implicit in this scenario is the decision not to build any LWRs that begin power production after 2000. The decision to halt reactor construction would be made in 1990 or earlier. Therefore, a decision in the year 2000 to reprocess spent fuel to recycle in LWRs is unlikely, but was included for comparison. If the decision to recycle is made in 1990, the loss of energy production potential is $12 \%$ for Case A, $4 \%$ for Case B and less than $1 \%$ for Case $C$.

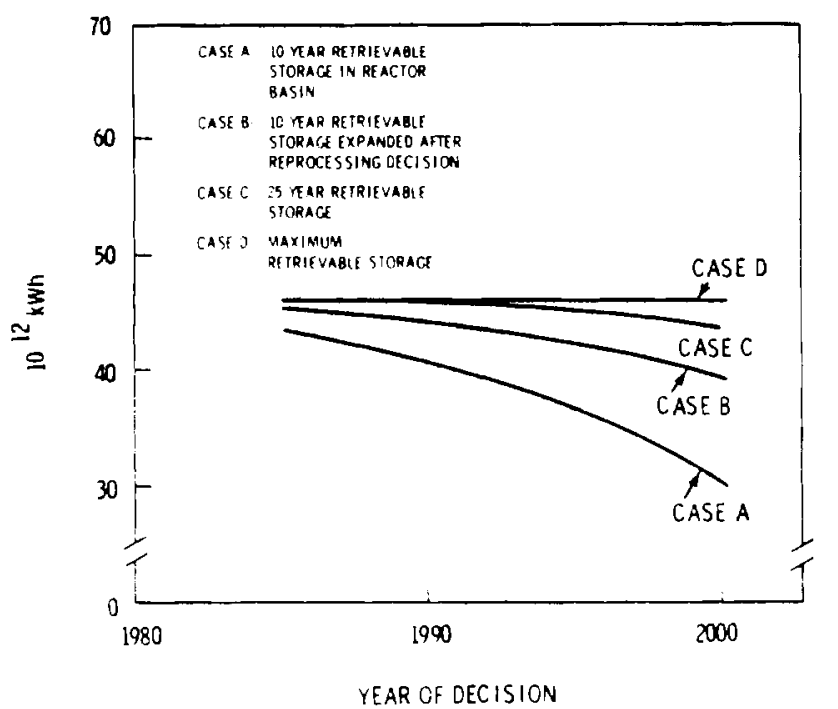

FIGURE 6. Potential Additional Energy from Modified LWR Recycle (Modified LWR Growth ScheduTe) 
The growth of LMFBR capacity of the three decision dates is similar to but slightly less than that depicted in Figures 2, 3, and 4 for the other LWR scenario. Figure 7 summarizes the results. For a decision to build breeder reactors, made no later than $1990,85 \%$ of the potentially achievable LMFBR generating capacity (Case $D$ ) can be realized even if no post reactor basin retrievable storage is provided (Case A). Over $95 \%$ of the potential generating capacity is achievable if retrievable storage is built after such a decision is made (Case B) and $99 \%$ is achievable if fuel is retievably stored for a maximum of 25 years.

The spent fuel storage times for this scenario for the FIFO method are essentially unchanged from those given in Tables 3 and 4 . The storage times for the LIFO method are increased 1 or 2 years.

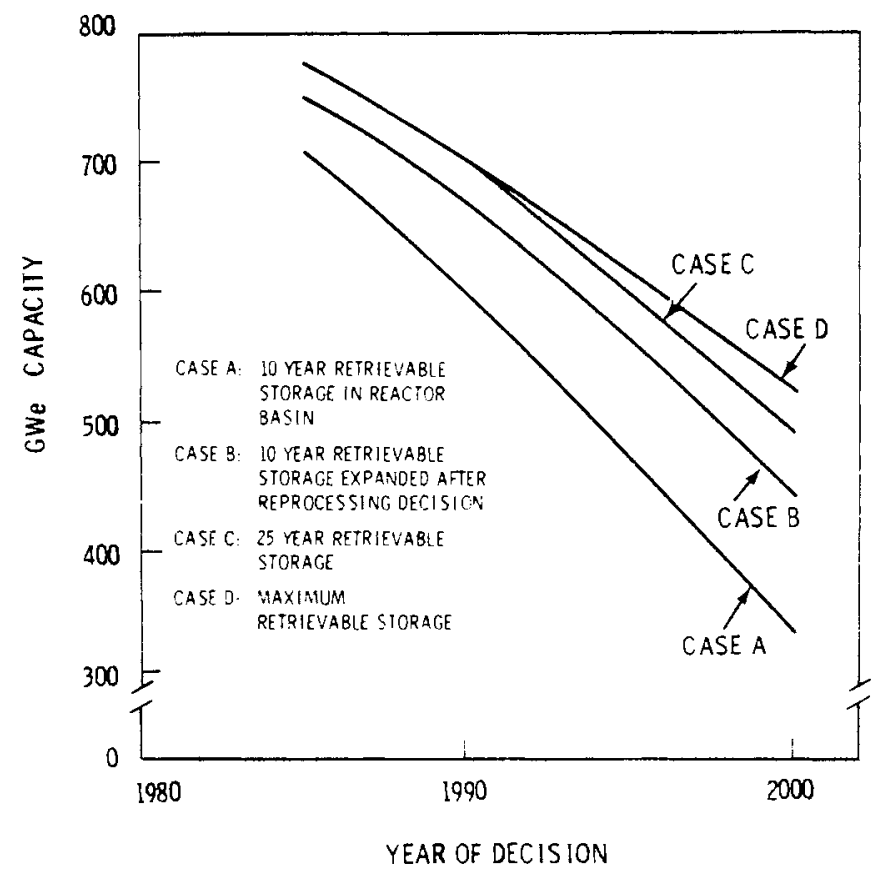

FIGURE 7. Potential LMFBR Generating Capacity in 2040 (Modified LWR Growth Schedule) 


\section{ANALYSIS ASSUMPTIONS}

The additional energy production achievable by recycling spent fuel in LWRs (Figures 1 and 6 ) was calculated assuming self-generating recycle of the amount of spent fuel retrievably stored for each of the cases.

The breeder buildup results depicted in Figures 2, 3, and 4 were based on the breeder plutonium requirements given in Table 6 . The key analysis assumptions were:

1) 10 year delay between a decision to reprocess and startup of first LWR reprocessing plant;

2) LWR reprocessing capability buildup to a levelized rate in each case sufficient to reprocess all of the retrievably stored spent fuel within a 40 year period;

3) Initial breeder core required 2 years prior to startup;

4) LMFBR fuel reprocessing buildup as required subject to the constraint of a 2 year minimum out of reactor time.

TABLE 6. Pu Flows for HEDL Large Pin, 800 MWe, 2500 MWt LMFBR

$\begin{array}{ll}\text { First Core } & 2800 \mathrm{~kg} \\ \text { Reload } & 1400 \mathrm{~kg} \\ \text { lst Discharge } & 1500 \mathrm{~kg} \\ \text { 2nd Discharge } & 1600 \mathrm{~kg} \\ \text { Equilibrium } & 1700 \mathrm{~kg}\end{array}$




\section{DISTRIBUTION}

No. of

Copies

OFFSITE

A. A. Churm

DOE Chicago Patent Group

9800 S. Cass Ave.

Argonne, IL 60439

C. R. Cooley

DOE Headquarters

Washington, DC 20545

J. B. Work

DOE Headquarters

Washington, DC 20545

2 A. J. Roberts

DOE, Nevada Operations Office

P.0. Box 14100

Las Vegas, NV 89114

F. D. King

Savannah River Laboratory

P.0. Drawer E

Aiken, SC 29801

F. L. Harris

Kaiser Engineers, Inc.

303 Lakeside Dr.

Oakland, CA 94666

2 D. C. Durrill

Westinghouse Electric Corporation Advanced Energy Systems Division

E. Pittsburgh, PA 15112

2 J. B. Wright

Westinghouse Electric Corporation Advanced Energy Systems Division

E. Pittsburgh, PA 15112
No. of

Copies

ONSITE

6 DOE Richland Operations

W. E. Cawley

0 . J. Elgert

F. L. Goldsberry

R. B. Goranson

P. G. Harris

H. E. Ransom

5 Hanford Engineering Development Laboratory

D. A. Cantley (3)

J. F. Fletcher

R. L. Knecht

5 Rockwell Hanford Operations

W. J. Kurzeka (2)

D. A. Turner

D. D. Wodrich

Cognizant Rockwell Engineer

21 Pacific Northwest Laboratory

R. M. Fleischman

E. T. Merrill

M. K. White (10)

I. S. Levy (2)

R. D. Widrig (2)

Publishing Coordination (2)

Technical Information (5) 
